\title{
Physiological Studies on Growth and Fruiting of Washington Navel Orange Trees
}

\author{
Atawia, A. A. R. E. ; F. M. Abd El-Latif ; H. E. M. El-Bedway and T. B. El-Sayed \\ Faculty of Agriculture, Moshtohor, Benha University, Egypt.
}

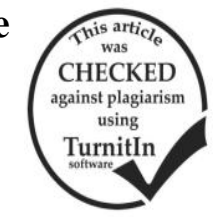

\section{ABSTRACT}

This investigation was carried out during the two successive seasons of 2013 and 2014 in a private orchard located at "New Gamgarah, Benha" district, Qalyubeia Governerate to study the effect of some stimulating substances i.e., $\left(\mathrm{GA}_{3}\right.$, NAA, sea-weeds, yeast extract and proplis) at different concentrations on some fruiting parameters and fruit properties as well as leaf nutritional status of Washington navel orange trees budded on sour orange reatstock. Trees under study were 18-year-old, grown in a clay leamy soil and planted at 5 meters apart under flood irrigation system. Obtained results revealed that all investigated stimulating substances treatments under study as foliar spray at various concentrations resulted in a significant increase in fruit set percentage and yield either $\mathrm{Kg} /$ tree or ton/feddan as well as the yield increment \% in relation to the control, however decreased the percentage of fruit drop in comparison with the control during both seasons of study. Moreover, both fruit physical characters such as (fruit weight, volume, height, diameter and fruit shap index) and fruit chemical properties (TSS \%, total acidity and TSS \%, /acid ratio) were significantly improved as a result of sprayed trees with the above mentioned stimulating substances treatments. In addition to that, leaf nutrient contents were improved in all studied treatments from the standpoint of statistic as compared to the control during both the first and second seasons of study. Generally, it could be concluded that, most of investigated treatments resulted in a positive and significant effect on most studied properties, since both treatments of active dry yeast at $\left(150\right.$ and $\left.100 \mathrm{ml}^{3} / \mathrm{L}\right)$ were the most effective treatments for increasing both fruit set $\%$ and productivity while decreasing fruit drop $\%$ as well as improving both the most studied of fruit properties and leaf nutrient contents of Washington navel orange trees

\section{INTRODUCTION}

Citrus is considered one of the most important fruit crops grown in many tropical and subtropical countries. In Egypt, citrus has a great attention and widely cultivated due to importance for local consumption (high nutritive value) and economic importance however, represent a main source for foreign currencies by exportation to the European countries.

Undoubtedly, there are many problems facing fruit trees growers which effect the productivity and fruit quality of citrus trees. High costs of mineral fertilizers needed to fruit trees (more than $40 \%$ of citrus production costs are devoted to fertiligation practices) is one of these problems, addition to that the use of mineral fertilizers have an increased rale in the health problems of mankind. Moreover, they are considered as air, soil and water polluting agent results from leached chemical fertilization into the soil led to disturbance in the natural biological balance in the soil and accumulate in feed chain causing hazardous effects for human health.

According to the 2015 statistics inventory of the Egyptian Ministry of Agriculture, the total acreage of citrus was (533835) feddans with a total area including (449601) feddans as a fruitful area with a total production a bout ( 4646579 ) tons .

Many researchers reperted that spraying some fruit trees including citrus trees with different stimulating substances such as sea-weeds extract, active dry yeast extract, GA3, NAA and Proplis, at the different concentrations enhanced vegetative growth, increasd fruit set consequantly increased productivity and inproved the most fruit properties as well as inproved leaf nutritional status of trees as mentioned by Atawia and El-Desouky (1998); Fornes et. al., (2002);AbdEl-Maged et. al., (2007); Abd El-motty et. al., (2010); Khafagy et. al., ((2010); Faissal et. al., (2013); Ghosh et. al., (2013); Khan et. al., (2014); Ullah et. al., (2014)) Mohmoud et. al., (2015) and Ayed et. al., (2016).

Therefore, the present investigation was planned and carried out on Washington navel orange trees (Citrus sinensis L.) grown in a clay loamy soil to study the most effective treatments of some stimulating substances i.e.,
(GA3, NAA, Sea-weed extract, active dry yeast extract and proplis) at different concentrations as foliar spray through studing their effect on some fruiting parameters and some fruit physical and chemical properties as well as leaf nutritional status of Washington navel orange trees

\section{MATERIALS AND METHODS}

The present investigation was carried out during the two successive seasons of 2013 and 2014 in private orchard located at (New Gamgarah, Benha) region, Qalyubeia governorate, Egypt (18) year old trees of orange "Washington navel" cv. were the plant materials in this study.

Fourty four healthy fruitful of Washington navel orange trees cv., budded on sour orange rootstock were carefully selected and devoted for achieving this work. The selected trees were nearly uniform as possible as we could in their growth vigour, free from diseases, grown in a clay loamy soil and planted at 5 meters apart under flood irrigation system. All trees in this investigation received regularly the same horticultural practices adopted in this region.

With respect to the differential measurements of some fruiting parameters and fruit characteristics quality of Washington navel orange trees in response to the two concentrations or rates of some stimulating chemicals under study i.e., (NAA, GA 3 , Yeast, sea-weeds and proplis) as foliar sprays were concerned.

Accordingly, the investigated stimulating materials of foliar spray treatments were as follows :

1- Control treatment (weter spray only).

2- Spraying with NAA at $25 \mathrm{ppm}$.

3- Spraying with NAA at $50 \mathrm{ppm}$.

4- Spraying with $\mathrm{GA}_{3}$ at $75 \mathrm{ppm}$.

5- Spraying with $\mathrm{GA}_{3}$ at $150 \mathrm{ppm}$.

6- Spraying with active dry yeast at $\left(100 \mathrm{~mL}^{3} / \mathrm{L}\right.$. $)$

7- Spraying with active dry yeast at $\left(150 \mathrm{~mL}^{3} / \mathrm{L}\right.$.)

8- Spraying with sea-weeds at $\left(150 \mathrm{~mL}^{3} / \mathrm{L}\right)$.

9- Spraying with sea-weeds at $\left(200 \mathrm{~mL}^{3} / \mathrm{L}\right)$.

10 - Spraying with proplis at $1.4 \mathrm{gm} / \mathrm{L}$.

11 - Spraying with proplis at $2.8 \mathrm{gm} / \mathrm{L}$. 
Each of NAA, GA G $_{3}$ active dry yeast, sea-weeds and proplis were sprayed three times for all seasons, the first at full bloom (on March), the second after fruit set, ( one monlh later on April) and the third one was sprayed before june drop during both seasons of study taking into consideration that super film at $0.1 \%$ was added as surfactant agent to all solution treatments including the control. Moreover, 5 liter of spray solutions were found to be used to cover the whole foliage, of tree canopy.

The complete randomized blocks design was used for arranging the above mentioned eleven treatments with three replications, whereas each replicate was represented by a single tree. "additionally" elven trees were needed beside additional ones (an individual tree per each treatment) were also included, so a reserve would be available.

Methodology which has been followed in this study is being determined as follows :

\section{- Fruiting parameters:}

a-Fruit set percentage :

Both the total number of flowers at full bloom and the initial number of fruits at the end of blooming stage (set fruitlets) were counted and recorded per each tree for all treatments then, fruit set percentage was calculated by the following equation according to Westwood (1978).

$$
\text { Fruit Set } \%=\frac{\text { Number of set fruitlets }}{\text { Total number of flowers at full bloom }} \times 100
$$

\section{b. yield and yield increment $\%$ in relation to the control :}

Average yield per tree either as $\mathrm{Kg} /$ tree or ton per feddan for each treatment was determined at the harvesting periode. Moreover, the yield increment percentage for each treatment as compared to the control (the efficiency of treatment) was estimated by the following equation according to kebeel (1999).

$$
\text { Yield increment } \%=\frac{\text { Yield per treatment }- \text { Yield per control }}{\text { Yield per control }} 100
$$

\section{2-Fruit characteristics :}

Samples of twenty mature fruits at harvesting periode (at maturity stage) from each replicate were randomly collected and the following properties of both physical and chemical were determined as follows :

\section{a- Fruit physical characters :}

average of fruit weight (gm), volume $\left(\mathrm{mL}^{3}\right)$, dimensions ( height and diameter in $\mathrm{mm}$.) and shape index ( hieght / diameter ratio).

\section{b-Fruit chemical characters :}

The following chemical characters of three fruit juice for mature fruits were determined as follows:

\section{Total soluble solids percentage (TSS\%) :}

Total soluble solids $\%$ in fruit juice was determined as percentage (TSS\%) by using a Carl-Zeiss hand refractometer according to Chen and Mellenthin (1981).

Total titratable acidity (mg citric acid / 100mg juice) :

Total acidity of Fruit juice was estimated as the percentage by the titration against $0.1 \mathrm{~N}$ of sodium hydroxide in the presence of phenolphthaline (1\%) as an indicator according to A.O.A.C. (2000).

\section{Total soluble solids content / acid ratio :}

TSS / acid ratio was estimated from obtained date recorded of fruit juic TSS and total acidity by dividing TSS $\%$ over total acidity.

\section{3- Leaf nutrient contents :}

Leaf contents of some macro-elements $(\mathrm{N}, \mathrm{P}$ and $\mathrm{K})$ and some micro- nutrients (Fe, $\mathrm{Zn}$ and $\mathrm{Mn}$ ) were determined. The following procedures were used.

Total nitrogen content :

Total nitrogen content of dried samples were determined by the modified micro-kjeldahl method as described by Pregl (1945).

Total phosphorus content :

Total phosphorus content was carried out colorimetrically using a Spekal spectrophotometer at 882.0 u.v. according to the method described by Murphy and Riely (1962) Meanushile, leaf K, Fe, Zn and Mn contents were determined by using the Atomic Absorption spectrophotometer (3300) according to Jackson and Ulrich (1959) and Chapman and pratl (1961).

Statistical banalysis:

All the obtained data during the two experimantal seasons of study were statistically analyzed using the analysis of variance method according to Snedecor and Cochran (1990). However, means were distinguished by the Duncan's multiple range test (Duncan, 1955).

\section{RESULTS AND DISCUSSION}

\section{1-Fruiting parameters :}

Concerning the fruiting parameters under study as fruit set and fruit drop, productivity as $\mathrm{kg} /$ tree or yield as ton per feddan and yield increment $\%$ In relation to the control in response to all the investigated stimulating substances treatments, data in this respect represented in both Tables (1\&2).

\section{1-a- Percentages of fruit set and fruit drop :}

Data tabulated in Table (1) declered that, the percentage of fruit set responded significantly to all treatments investigated of stimulating substances under study as compared to the control treatment. However, all treatments of stimulating substances resulted in a significant increase in fruit set \% as compared untreated trees (control). Moreover, trees sprayed with both 150 and $100 \mathrm{~mL}^{3} / \mathrm{L}$ of active dry yeast extract were statistically the superior as exhibited significantly the highest values of fruit set $\%$ during both seasons of study. On the other hand, results showed that the opposite trend was true with the control treatment which was statistically the inferior as resulted in a significant least values of fruit set $\%$ in the two experimental seasons. In Addition to that, the other remain stimulating substances treatments recorded statistically in between values the above - mentioned two extents in this regard. Such trend was detected during both 2013 and 2014 seasons of study.

With respect to the percentage of fruit drop, obtained data in the same Table showed obvicusly that fruit drop $\%$ was greatly affected by different investigated stimulating substances treatments however, all used treatments succeded in decreasing the percentage of fruit drop as compared to the control treatment which showed statistically the highest values and the greatest percentage of fruit drop in both the first and second seasons of study. Whereas, both treatments of active dry yeast extract at $(150$ and $100 \mathrm{~mL} 3 / \mathrm{L})$ induced statistically the least values in fruit drop \% followed by treatment of sea-weeds extract at $(200 \mathrm{~mL} 3 / \mathrm{L})$. Moreover, the remain stimulating substances treatments of sea-weeds extract at $150 \mathrm{~mL} 3 / \mathrm{L}$; Proplis; GA3 and NAA were statistically in between the 
aforesaid two extants as their effect on percentage of fruit drop of Washington navel orange trees. Such trends were detected during both 2013 and 2014 season of study.

The obtained results concerning the percentages of both fruit set and fruit drop are in conformity with those previonsly reported by Atawia and El-Desouky (1997), Khafagy et.al., (2010), El-Shazly and Mustafa (2013) and Ayed (2016) on :Washington navel orange trees.

Table 1. Response of some fruiting parameters (Fruit set $\%$ and fruit drop \%) of Washington navel orange trees to some stimulating substances treatments during both 2013 and 2014 seasons.

\begin{tabular}{lcccc}
\hline \multirow{2}{*}{ Treatments } & \multicolumn{2}{c}{ Fruit set \% } & \multicolumn{2}{c}{ Fruit drop \% } \\
\cline { 2 - 5 } & $\mathbf{2 0 1 3}$ & $\mathbf{2 0 1 4}$ & $\mathbf{2 0 1 3}$ & $\mathbf{2 0 1 4}$ \\
\hline Control (tap water) & $9.82 \mathrm{~F}$ & $10.18 \mathrm{~J}$ & $87.09 \mathrm{~A}$ & $83.62 \mathrm{~A}$ \\
$\mathrm{GA}_{3}$ at $75 \mathrm{ppm}$. & $13.14 \mathrm{C}$ & $13.94 \mathrm{E}$ & $83.10 \mathrm{BC}$ & $80.58 \mathrm{C}$ \\
$\mathrm{GA}_{3}$ at $150 \mathrm{ppm}$. & $13.07 \mathrm{C}$ & $13.95 \mathrm{E}$ & $82.16 \mathrm{BC}$ & $80.61 \mathrm{C}$ \\
$\mathrm{NAA}$ at $25 \mathrm{ppm}$. & $11.85 \mathrm{D}$ & $12.02 \mathrm{G}$ & $81.78 \mathrm{C}$ & $74.87 \mathrm{D}$ \\
$\mathrm{NAA}$ at $50 \mathrm{ppm}$. & $11.91 \mathrm{D}$ & $12.91 \mathrm{~F}$ & $81.45 \mathrm{C}$ & $79.61 \mathrm{C}$ \\
Sea-Weeds at $150 \mathrm{~mL}^{3} / \mathrm{L}$ & $14.82 \mathrm{~B}$ & $15.92 \mathrm{D}$ & $78.41 \mathrm{D}$ & $73.56 \mathrm{DE}$ \\
Sea-Weeds at $200 \mathrm{~mL}^{3} / \mathrm{L}$ & $14.90 \mathrm{~B}$ & $16.82 \mathrm{C}$ & $77.37 \mathrm{DE}$ & $74.21 \mathrm{D}$ \\
Yeast extract at $100 \mathrm{~mL}^{3} / \mathrm{L}$ & $16.91 \mathrm{~A}$ & $17.39 \mathrm{AB}$ & $76.51 \mathrm{E}$ & $72.00 \mathrm{EF}$ \\
Yeast extract at $150 \mathrm{~mL}^{3} / \mathrm{L}$ & $16.98 \mathrm{~A}$ & $17.54 \mathrm{~A}$ & $72.75 \mathrm{~F}$ & $70.34 \mathrm{~F}$ \\
Proplis at $1.4 \mathrm{gm} / \mathrm{L}$ & $10.96 \mathrm{E}$ & $11.30 \mathrm{I}$ & $83.70 \mathrm{BC}$ & $80.64 \mathrm{C}$ \\
Proplis at $2.8 \mathrm{gm} / \mathrm{L}$ & $11.00 \mathrm{E}$ & $11.54 \mathrm{H}$ & $84.66 \mathrm{~B}$ & $82.51 \mathrm{~B}$ \\
\hline
\end{tabular}

b- Productivity (Yield either as kgs/trees or tons/fed. And yield increment \% in relation to the control) :

Data obtained during both 2013 and 2014 seasons of experimental study and tabulated in Table (2) revealed obviously that, the response yield of Washington navel orange trees expressed either as $\mathrm{Kg}$ /tree or ton/feddan to the different investigated stimulating substances treatments under study followed approximately the same trend previously detected with the percentage of fruit set. Since, the greatest and the heaviest yields $(\mathrm{kg} /$ tree and ton
/ feddan) were always in significant relationship to the sprayed trees with active dry yeast extract at 150 and 100 $\mathrm{mL} 3$ treatments. On the contrary, the lightest crop and the lowest values of yields ( $\mathrm{Kg} /$ tree and ton / feddan) were statistically inclosed relationship to those Washington navel orange trees sprayed with tap water only (control treatment). On the other hand, results indicated that, trees sprayed with sea-weeds treatment ranked statistically second to the superiorty treatment (yeast extract) while, sprayed trees with GA3 treatments ranked statistically third. Moreover, both (NAA) and (proplis) treatments came descendinglyfourth and fifth from the stand point of statistic. In addition to that, the higher concentration for any investigated stimulating substances was more effective than the lower one on both tree yield in Kgs and yield as ton/feedan especially in the first season of stuy.

With respect to the yield increment percentage in relation to the control, data obtained in Table (2) showed clearly that, the response typically followed the same trend previously detected with above mentioned fruiting character of yield either $\mathrm{kg} /$ tree or ton / feddan during both 2013 and 2014 seasons of study.

Furthermore, the higher rates of any stimulating substances treatments were more effective than the lower corresponding substance for increasing yield increament $\%$ in relation to the control such trend was true during both the first and second seasons of experimental study.

With regard to the effect of the investigated stimulating substances above mentioned on productivity measurements of Washington navel orange a similar observations were also achieved by many investigators, Castrol et. al., (1998), El-Maged et. al., (2007), Abd ElMatty et. al., (2010), Mounz-Fambuena et. al., (2012), Wang et. al., (2013), Gambetta et. al., (2014) and Ayed (2016).

Table 2. Response of some fruiting parameters (yield $\mathrm{kg} / \mathrm{tree}$, ton per feddan and yield increment $\%$ in relation to the control) of Washington navel orange trees to some stimulating substances treatments during both 2013 and 2014 seasons.

\begin{tabular}{lcccccc}
\hline \multirow{2}{*}{ Treatments } & \multicolumn{2}{c}{ Yield (Kg/tree) } & \multicolumn{2}{c}{ Yield (ton / feddan) } & \multicolumn{2}{c}{ Yield Increment \% in Relation to the control } \\
\cline { 2 - 6 } & $\mathbf{2 0 1 3}$ & $\mathbf{2 0 1 4}$ & $\mathbf{2 0 1 3}$ & $\mathbf{2 0 1 4}$ & $\mathbf{2 0 1 3}$ \\
\hline Control (tap water) & $46.93 \mathrm{~F}$ & $58.45 \mathrm{~F}$ & $7.98 \mathrm{f}$ & $9.94 \mathrm{~F}$ & $00.01 \mathrm{I}$ \\
$\mathrm{GA}_{3}$ at $75 \mathrm{ppm}$. & $51.76 \mathrm{D}$ & $62.66 \mathrm{E}$ & $8.80 \mathrm{D}$ & $10.65 \mathrm{E}$ & $10.29 \mathrm{~F}$ \\
$\mathrm{GA}_{3}$ at $150 \mathrm{ppm}$. & $53.86 \mathrm{C}$ & $63.08 \mathrm{E}$ & $9.16 \mathrm{C}$ & $10.72 \mathrm{E}$ & $14.77 \mathrm{E}$ & $7.20 \mathrm{H}$ \\
$\mathrm{NAA}$ at $25 \mathrm{ppm}$. & $49.87 \mathrm{DE}$ & $70.63 \mathrm{C}$ & $8.48 \mathrm{DE}$ & $12.01 \mathrm{C}$ & $6.26 \mathrm{GH}$ & $7.92 \mathrm{D}$ \\
$\mathrm{NAA}$ at $50 \mathrm{ppm}$. & $50.58 \mathrm{D}$ & $71.70 \mathrm{C}$ & $8.60 \mathrm{D}$ & $12.19 \mathrm{C}$ & $7.78 \mathrm{G}$ & $20.83 \mathrm{E}$ \\
Sea-Weeds at $150 \mathrm{~mL}^{3} / \mathrm{L}$ & $56.13 \mathrm{BC}$ & $77.71 \mathrm{~B}$ & $9.54 \mathrm{BC}$ & $13.21 \mathrm{~B}$ & $19.97 \mathrm{D}$ & $22.65 \mathrm{D}$ \\
Sea-Weeds at $200 \mathrm{~mL}^{3} / \mathrm{L}$ & $57.39 \mathrm{~B}$ & $78.61 \mathrm{~B}$ & $9.76 \mathrm{~B}$ & $13.36 \mathrm{~B}$ & $22.28 \mathrm{C}$ & $31.97 \mathrm{C}$ \\
Yeast extract at $100 \mathrm{~mL}^{3} / \mathrm{L}$ & $59.06 \mathrm{AB}$ & $80.74 \mathrm{~A}$ & $10.04 \mathrm{AB}$ & $13.73 \mathrm{~A}$ & $25.84 \mathrm{~B}$ & $33.94 \mathrm{~B}$ \\
Yeast extract at $150 \mathrm{~mL}^{3} / \mathrm{L}$ & $61.18 \mathrm{~A}$ & $81.72 \mathrm{~A}$ & $10.40 \mathrm{~A}$ & $13.89 \mathrm{~A}$ & $30.36 \mathrm{~A}$ & $38.10 \mathrm{~A}$ \\
Proplis at $1.4 \mathrm{gm} / \mathrm{L}$ & $47.01 \mathrm{~F}$ & $66.47 \mathrm{D}$ & $7.99 \mathrm{~F}$ & $11.30 \mathrm{D}$ & $00.18 \mathrm{I}$ \\
Proplis at $2.8 \mathrm{gm} / \mathrm{L}$ & $49.11 \mathrm{E}$ & $69.23 \mathrm{CD}$ & $8.35 \mathrm{E}$ & $11.74 \mathrm{CD}$ & $5.00 \mathrm{H}$
\end{tabular}

\section{2-Fruit quality :}

Fruit Physical Properties :

Fruit weight and volume :

Concerning the fruit weight (gm) and fruit volume $\left(\mathrm{mL}^{3}\right)$ as affected by the different investigated stimulating substances treatments, data obtained and tabulated in Table (3) indicated clearly that, both studied properties were increased by all investigated treatments either at higher or lower concentrations however, these increases were significant as compared to the control trees during both 2013 and 2014 seasons of study. Moreover, it could be noticed that, the heaviest fruits were resulted from trees sprayed with the highest concentration of both proplis and sea-weeds extract i.e., (2.8 $\mathrm{gms} / \mathrm{L}$ and $200 \mathrm{~mL}^{3} / \mathrm{L}$ ) during the two seasons, respectively, On the other hand, obtained results regarding fruit volume $\left(\mathrm{mL}^{3}\right)$ followed nearly the same trend previously detected with fruit weight whereas, the biggest and the greatest values of fruit volume were exhibited from the two previous treatments in the two seasons. On the contrary, both treatments of control and NAA at $25 \mathrm{ppm}$ induced significantly the lightest weight and the smallest volume of orange fruits through the first and second seasons. In addition, other stimulating treatments $\left(\mathrm{GA}_{3}\right.$ and active dry yeast 
extract), respectively, recorded in between values with tendency of variability in their effectiveness as compared to above mentioned two extents. Such trend was true during both 2013 and 2014 seasons of study.

Table 3. Response of some fruit physical characters (fruit Weight and fruit volume) of Washington navel orange trees to different stimulating substances treatments during both 2013 and 2014 seasons.

\begin{tabular}{lcccc}
\hline \multirow{2}{*}{ Treatments } & \multicolumn{2}{c}{ Fruit weight $\mathbf{( g m )}$} & \multicolumn{2}{c}{ Fruit volume $\left.\mathbf{( m L}^{\mathbf{3}}\right)$} \\
\cline { 2 - 5 } & $\mathbf{2 0 1 3}$ & $\mathbf{2 0 1 4}$ & $\mathbf{2 0 1 3}$ & $\mathbf{2 0 1 4}$ \\
\hline Control (tap water) & $199.0 \mathrm{~F}$ & $197.3 \mathrm{~F}$ & $186.0 \mathrm{H}$ & $194.7 \mathrm{G}$ \\
$\mathrm{GA}_{3}$ at $75 \mathrm{ppm}$. & $208.0 \mathrm{E}$ & $210.7 \mathrm{E}$ & $202.0 \mathrm{~F}$ & $203.3 \mathrm{EF}$ \\
$\mathrm{GA}_{3}$ at $150 \mathrm{ppm}$. & $256.7 \mathrm{~B}$ & $264.0 \mathrm{~A}$ & $238.0 \mathrm{C}$ & $255.7 \mathrm{~B}$ \\
$\mathrm{NAA}$ at $25 \mathrm{ppm}$. & $200.0 \mathrm{~F}$ & $198.0 \mathrm{~F}$ & $190.7 \mathrm{G}$ & $195.3 \mathrm{G}$ \\
NAA at $50 \mathrm{ppm}$. & $202.7 \mathrm{EF}$ & $201.3 \mathrm{~F}$ & $205.7 \mathrm{EF}$ & $202.3 \mathrm{EF}$ \\
Sea-Weeds at $150 \mathrm{~mL}^{3} / \mathrm{L}$ & $209.0 \mathrm{E}$ & $217.7 \mathrm{DE}$ & $212.7 \mathrm{DE}$ & $205.3 \mathrm{EF}$ \\
Sea-Weeds at $200 \mathrm{~mL}^{3} / \mathrm{L}$ & $249.0 \mathrm{~B}$ & $253.3 \mathrm{~B}$ & $256.0 \mathrm{~B}$ & $258.7 \mathrm{AB}$ \\
Yeast extract at $100 \mathrm{~mL}^{3} / \mathrm{L}$ & $219.7 \mathrm{D}$ & $220.0 \mathrm{D}$ & $215.3 \mathrm{D}$ & $208.3 \mathrm{E}$ \\
Yeast extract at $150 \mathrm{~mL}^{3} / \mathrm{L}$ & $236.3 \mathrm{C}$ & $235.0 \mathrm{C}$ & $234.0 \mathrm{C}$ & $246.0 \mathrm{C}$ \\
Proplis at $1.4 \mathrm{gm} / \mathrm{L}$ & $231.7 \mathrm{C}$ & $221.7 \mathrm{D}$ & $218.0 \mathrm{D}$ & $216.7 \mathrm{D}$ \\
Proplis at $2.8 \mathrm{gm} / \mathrm{L}$ & $282.3 \mathrm{~A}$ & $267.0 \mathrm{~A}$ & $290.7 \mathrm{~A}$ & $264.3 \mathrm{~A}$ \\
\hline
\end{tabular}

\section{Fruit dimensions :}

As for fruit dimensions (fruit height and diameter in $\mathrm{mm}$.) in response to all investigated stimulating substances treatments under study, it is evident from results tabulated in Table (4) that fruit height significantly increased by all tested stimulating treatments as compared to the control treatment which showed the least significant value in this respect during both 2013 and 2014 seasons of study. On the other hand, the highest values of fruit height resulted from trees sprayed with proplis at rate of $2.8 \mathrm{gm} / \mathrm{L} /$ tree in the first season while, in the second one the treatments of sea-weeds extract at $\left(200 \mathrm{~mL}^{3} / \mathrm{L}\right), \mathrm{GA}_{3}$ at 75 and150
ppm.Active yeast extract at $\left(150 \mathrm{~mL}^{3} /\right.$ tree) and proplis at 2.8 and $1.4 \mathrm{gms} / \mathrm{L} /$ tree) treatments, respectively, whereas, differences between the above mentioned treatments were no significant as compared to each other. In addition to that, the other remain treatments were responded in between to both above mentioned extents from the standpoint of statistic. Moreover, with respect to the fruit diameter, data in the same Table indicated that, all investigated treatment of stimulating substances in this study followed nearly asimilar trend to the above mentioned and detected with fruit height during both the first and second seasons of study.

Table 4. Response of some fruit physical properties (fruit height, diameter and fruit shape index) of Washington navel orange trees to different stimulating substances treatments during both 2013 and 2014 seasons.

\begin{tabular}{|c|c|c|c|c|c|c|}
\hline \multirow{2}{*}{ Treatments } & \multicolumn{2}{|c|}{ Fruit height (mm) } & \multicolumn{2}{|c|}{ Fruit diameter (mm) } & \multicolumn{2}{|c|}{ Fruit shape index (h/d) } \\
\hline & 2013 & 2014 & 2013 & 2014 & 2013 & 2014 \\
\hline Control (tap water) & $73.5 \mathrm{E}$ & $73.3 \mathrm{C}$ & $68.5 \mathrm{E}$ & $70.6 \mathrm{E}$ & $1.08 \mathrm{AB}$ & $1.04 \mathrm{BD}$ \\
\hline $\mathrm{GA}_{3}$ at $75 \mathrm{ppm}$. & $73.8 \mathrm{E}$ & $78.4 \mathrm{~A}$ & $72.3 \mathrm{CD}$ & $71.6 \mathrm{CE}$ & $1.02 \mathrm{DE}$ & $1.10 \mathrm{~A}$ \\
\hline $\mathrm{GA}_{3}$ at $150 \mathrm{ppm}$. & $81.5 \mathrm{BC}$ & $78.7 \mathrm{~A}$ & $76.3 \mathrm{AB}$ & $74.2 \mathrm{AB}$ & $1.07 \mathrm{AC}$ & $1.06 \mathrm{AC}$ \\
\hline NAA at $25 \mathrm{ppm}$. & $73.7 \mathrm{E}$ & $73.3 \mathrm{C}$ & $70.5 \mathrm{DE}$ & $71.5 \mathrm{CE}$ & $1.05 \mathrm{AD}$ & $1.03 \mathrm{BD}$ \\
\hline NAA at $50 \mathrm{ppm}$. & $73.7 \mathrm{E}$ & $74.9 \mathrm{BC}$ & $71.5 \mathrm{DE}$ & $71.1 \mathrm{DE}$ & $1.04 \mathrm{BD}$ & $1.05 \mathrm{AC}$ \\
\hline Sea-Weeds at $150 \mathrm{~mL}^{3} / \mathrm{L}$ & $75.3 \mathrm{DE}$ & $75.4 \mathrm{BC}$ & $74.7 \mathrm{BC}$ & $72.4 \mathrm{BE}$ & $1.01 \mathrm{E}$ & $1.04 \mathrm{BD}$ \\
\hline Sea-Weeds at $200 \mathrm{~mL}^{3} / \mathrm{L}$ & $82.3 \mathrm{~B}$ & $79.1 \mathrm{~A}$ & $76.3 \mathrm{AB}$ & $73.38 \mathrm{AB}$ & $1.08 \mathrm{AB}$ & $1.08 \mathrm{AB}$ \\
\hline Yeast extract at $100 \mathrm{~mL}^{3} / \mathrm{L}$ & $77.8 \mathrm{CD}$ & $75.5 \mathrm{BC}$ & $75.1 \mathrm{BC}$ & $73.1 \mathrm{BD}$ & $1.04 \mathrm{BD}$ & $1.03 \mathrm{BD}$ \\
\hline Yeast extract at $150 \mathrm{~mL}^{3} / \mathrm{L}$ & $78.8 \mathrm{BD}$ & $78.3 \mathrm{~A}$ & $77.5 \mathrm{AB}$ & $74.4 \mathrm{AB}$ & $1.02 \mathrm{DE}$ & $1.05 \mathrm{AC}$ \\
\hline Proplis at $1.4 \mathrm{gm} / \mathrm{L}$ & $80.1 \mathrm{BC}$ & $76.7 \mathrm{AB}$ & $75.6 \mathrm{AC}$ & $73.5 \mathrm{AC}$ & $1.06 \mathrm{AC}$ & $1.06 \mathrm{AC}$ \\
\hline Proplis at $2.8 \mathrm{gm} / \mathrm{L}$ & $86.3 \mathrm{~A}$ & $77.4 \mathrm{~A}$ & $78.7 \mathrm{~A}$ & $75.6 \mathrm{~A}$ & $1.10 \mathrm{~A}$ & $1.03 \mathrm{BD}$ \\
\hline
\end{tabular}

Fruit shape index (fruit height / diameter ratio) :

With respect to the response of fruit shape index (fruit height / fruit diameter ratio) to all the investigated stimulating substances treatments, data in Table (4) displayed clearly that, no difinate trend during both seasons. Whereas, the greatest statistically values of fruit shape index in closed relationship with treatment of proplis at $(2.8 \mathrm{gm} / \mathrm{L})$ followed by both treatments of sea-weeds extract at $\left(200 \mathrm{~mL}^{3} / \mathrm{L}\right)$ and control in the first season with no significant differences between three treatments. However, in the second one both treatments of $\mathrm{GA}_{3}$ at $(75$ ppm) and sea-weads extract at $\left(200 \mathrm{~mL}^{3} / \mathrm{L}\right)$ showed the highest values of fruit shape index than the other investigated treatments under study. On the contrary, Washington navel orange trees sprayed with sea-weeds extract at $\left(150 \mathrm{~mL}^{3} / \mathrm{L}\right)$ resulted in significantly the least values of fruit shape index during the two seasons of study. Moreover, the other remain investigated treatments came in between with tendency variable in their effectiveness during both 2013 and 2014 seasons of study.

\section{Fruit chemical properties :}

TSS \%:

With regard to TSS \% as affected by the investigated stimulating substances treatments under study, obtained data represented in Table ( 5 ) displayed obviously that, TSS\% was responded significantly to the different studied stimulating treatments as compared to the control treatment during both 2013 and 2014 seasons of study. However, Washington navel orange trees sprayed with both active dry yeast extract at $\left(150 \mathrm{~mL}^{3} / \mathrm{L} /\right.$ tree $)$ and sea-weeds extract at $\left(200 \mathrm{~mL}^{3} / \mathrm{L} /\right.$ tree $)$ treatments in the first season and the treatment of active dry yeast extract at (150 $\mathrm{mL}^{3} /$ tree) in the second one exhibited the richest fruits in their content of TSS \% and induced fruits with the highest significant values in this respect. Whereas, the opposite trend was true with such navel orange trees sprayed with tap water only (control) treatment which resulted significantly in the poorest content and the least values TSS \% of fruit juice in both seasons of study. Moreover the other remain stimulating substances treatments were statistically responded in between to both above mentioned 
extents. Such trend was true during the two experimental seasons of study.

Total acidity \% :

Referring the effect of different investigated stimulating substances treatments on total acidity $\%$, it is worthy to notice during both 2013 and 2014 seasons from results obtained and represented in Table (5) that, the highest significant values of total acidity $\%$ was always in concomitant to such fruits produced by trees sprayed with top water (control) treatment in both seasons and seaweeds extract treatment at $\left(200 \mathrm{~mL}^{3} / \mathrm{L} /\right.$ tree $)$ in the second one only. However, Navel orange trees sprayed with both treatments of proplis at $(2.8 \mathrm{gm}$ and $1.4 \mathrm{gm} / \mathrm{L})$ resulted significantly in the lowest values of total acidity \% , respectively, with a significant difference between each other in the two seasons of study. Moreover, the other stimulating treatments under study were statistically responded in between to both above mentioned two extents. Such trends were detected during both the first and second seasons of study.

\section{TSS\%/ acid ratio :}

With respect to TSS\%/ acid ratio of fruit juice under study in response to the investigated stimulating treatments in both seasons, data in the same Table revealed obviously that all studied treatments resulted in a significant increase in fruit juice TSS/ acid ratio as compared to the control treatment (trees sprayed with tap water) which recorded the poorest content and the least value TSS/acid ratio of fruit juice. Moreover, trees sprayed with stimulating treatments of yeast extract at $\left(150 \mathrm{~mL}^{3} / \mathrm{L}\right)$, sea-weeds extract at $\left(200 \mathrm{~mL}^{3}\right)$ and GA3 at $(150 \mathrm{ppm})$ in the first season and treatments of yeast extract $\left(150 \mathrm{~mL}^{3}\right), \mathrm{GA}_{3}(150 \mathrm{ppm})$ and proplis at $(2.8 \mathrm{gms} / \mathrm{L})$ in the second one were the superior of TSS/acid ratio which exhibited the richest fruits and the highest values of TSS/acid ratio from the standpoint of statistic with no significant differences between each other. On the other hand, the other remain investigated treatments came intermediate the above mentioned two extents. Such trend was true in the 2013 and 2014 seasons of study.

Obtained data concerning the response of investigated fruit chemical characteristics to the studied stimulating treatments are in accordance with those previously reported by several researchers, Koo and Mayo (1995), Fathy and farid (1996), AbdEl-Maged et.al., (2007), Khan et.al., (2009), AbdEl-Mothy et.al., (2013), Ahmed et.al., (2013) and Ayed (2016) on some citrus trees.

Table 5. Response of some fruit chemical properties (TSS\%, total acidity and TSS/Acid ratio) of Washington navel orange trees to some stimulating substances treatments during both 2013 and 2014 seasons.

\begin{tabular}{|c|c|c|c|c|c|c|}
\hline \multirow{2}{*}{ Treatments } & \multicolumn{2}{|c|}{ TSS \% } & \multicolumn{2}{|c|}{ Total Acidity \% } & \multicolumn{2}{|c|}{ TSS / acid ratio } \\
\hline & 2013 & 2014 & 2013 & 2014 & 2013 & 2014 \\
\hline Control (tap water) & $9.33 \mathrm{G}$ & $10.00 \mathrm{~F}$ & $1.050 \mathrm{~A}$ & $1.037 \mathrm{~A}$ & $8.89 \mathrm{E}$ & $9.64 \mathrm{~F}$ \\
\hline $\mathrm{GA}_{3}$ at $75 \mathrm{ppm}$ & $10.33 \mathrm{E}$ & $10.33 \mathrm{E}$ & $1.030 \mathrm{BC}$ & $1.020 \mathrm{AC}$ & $10.03 \mathrm{D}$ & $10.15 \mathrm{E}$ \\
\hline $\mathrm{GA}_{3}$ at $150 \mathrm{ppm}$. & $11.33 \mathrm{~B}$ & $11.33 \mathrm{E}$ & $1.027 \mathrm{CD}$ & $1.013 \mathrm{BC}$ & $11.03 \mathrm{AB}$ & $11.19 \mathrm{AB}$ \\
\hline NAA at $25 \mathrm{ppm}$. & $10.67 \mathrm{D}$ & $11.00 \mathrm{C}$ & $1.030 \mathrm{BC}$ & $1.020 \mathrm{AC}$ & $10.36 \mathrm{C}$ & $10.78 \mathrm{C}$ \\
\hline NAA at $50 \mathrm{ppm}$. & $11.00 \mathrm{C}$ & 100. C & $1.013 \mathrm{D}$ & $1.010 \mathrm{C}$ & $10.88 \mathrm{~B}$ & $10.90 \mathrm{C}$ \\
\hline Sea-Weeds at $150 \mathrm{~mL}^{3} / \mathrm{L}$ & $10.67 \mathrm{D}$ & $10.67 \mathrm{D}$ & $1.033 \mathrm{~B}$ & $1.030 \mathrm{AB}$ & $10.33 \mathrm{C}$ & $10.36 \mathrm{D}$ \\
\hline Sea-Weeds at $200 \mathrm{~mL}^{3} / \mathrm{L}$ & $11.67 \mathrm{~A}$ & $11.33 \mathrm{~B}$ & $1.033 \mathrm{~B}$ & $1.033 \mathrm{~A}$ & $11.30 \mathrm{~A}$ & $10.97 \mathrm{BC}$ \\
\hline Yeast extract at $100 \mathrm{~mL}^{3} / \mathrm{L}$ & $11.00 \mathrm{C}$ & $11.33 \mathrm{~B}$ & $1.030 \mathrm{BC}$ & $1.020 \mathrm{AC}$ & $10.68 \mathrm{BC}$ & $11.11 \mathrm{~B}$ \\
\hline Yeast extract at $150 \mathrm{~mL}^{3} / \mathrm{L}$ & $11.67 \mathrm{~A}$ & $11.67 \mathrm{~A}$ & $1.033 \mathrm{~B}$ & $1.027 \mathrm{AC}$ & $11.30 \mathrm{~A}$ & $11.36 \mathrm{~A}$ \\
\hline Proplis at $1.4 \mathrm{gm} / \mathrm{L}$ & $10.00 \mathrm{~F}$ & $10.67 \mathrm{D}$ & $1.000 \mathrm{E}$ & $0.987 \mathrm{D}$ & $10.00 \mathrm{D}$ & $10.82 \mathrm{C}$ \\
\hline Proplis at $2.8 \mathrm{gm} / \mathrm{L}$ & $10.00 \mathrm{~F}$ & $10.33 \mathrm{E}$ & $0.923 \mathrm{~F}$ & $0.927 \mathrm{E}$ & $10.84 \mathrm{~B}$ & $11.15 \mathrm{AB}$ \\
\hline
\end{tabular}

\section{3-Leaf nutrient contents :}

a- Leaf macro-elements contents ( $N, P$ and $K)$ :

With respect to the leaf macro-elements contents

$(\mathrm{N}, \mathrm{P}$ and $\mathrm{K})$ of Washington navel orange trees in response to the effect of different investigated stimulanting substances treatments under study, data obtained and tabulated in Table (6) displayed clearly that, all studied stimulating treatments resulted in a significant increase in leaf $\mathrm{N}, \mathrm{P}$ and $\mathrm{K}$ contents as compared to the control treatment which recorded the least significant values and induced the poorest leaves in their contents of nitrogen (1.80 and 1.92), P.(0.27 and 0.30) and K (1.26 and 1.32) during the first and second seasons of study, respectively. On the other hand, both treatments of yeast extract either of higher or lower rates were the most effective treatments to increase both $\mathrm{N}$ and $\mathrm{P}$ contents in their leaves whereas, both treatments of Proplis were exhibited asignificant increase of $\mathrm{K}$ in their leaves. Moreover, the highest values and the richest leaves in their contents of $\mathrm{N}, \mathrm{P}$ and $\mathrm{K}$ were closely related to trees treated with the higher rate of above mentioned treatments, in spite of difference did not reach of significance between two rates. Such trends ware true during the two seasons of experimental study. In addition to that, the other remain treatments (Sea-weeds, $\mathrm{GA}_{3}$ and NAA) came in between the above mentioned two extents with averiable tendency of effectivenes. Anyhow, it could be observed that the higher rate of any investigated stimulating substances treatments under study was more effective than the lower ones in most cases to induced a significant increase N, P and K contents in the leaves. Such trend was detected during both 2013 and 2014 seasons of study.

Obtained results concering the leaf macro elements cotents (N, P and $\mathrm{K}$ ) of Washington navel orange trees to the different investigated treatments under study were supperted by the findings of several investigators Forne $e t$. al., (2002); Ghosh et. al., (2013); Khan et. al., (2014) and Ayed (2016) on citrus trees.

b. Leaf micro-nutrients content (Fe, $\mathrm{Zn}$ and $\mathrm{Mn}$ ):

Regarding the leaf micro- nutrients contents of (Fe, $\mathrm{zn}$ and $\mathrm{Mn}$ ) of Washington navel orange trees in response to the effect of different investigated stimulanting substances treatments under study, data obtained represented in Table (7) revealed obviously that the leaf $\mathrm{Fe}, \mathrm{Zn}$ and $\mathrm{Mn}$ contents were obviously responded to the various studied stimulanting substances treatments whereas, the richest leaves in their contents of $\mathrm{Fe}, \mathrm{Zn}$ and Mn were achieved by those trees treated with yeast extract treatment at higher rate. The superiority of the above mentioned treatment over the other investigated treatments was clearly observed during both the first and second seasons of study. On the other hand, obtained data indicated that, the lowest values and the poorest leaves in their contents of $\mathrm{Fe}, \mathrm{Zn}$ and $\mathrm{Mn}$ were in always inconcomitant to those Washington navel orange trees treated with the control treatment. Moreover, the other remain investigated treatments of stimulating substances 
were intermediate as compared with the oferesaid two extents from the standpoint of statistic. Furthermore, it could be noticed from obtained results that, treated trees with the higher rate from any studied stimulating substances tended to be relatively more effective than the lower ones. In other words, differences between the higher rate and the lower one from any investigated stimulating substances treetments above mentioned was significant as compared each other. Such trends were true during both 2013 and 2014 seasons of experimental study.

Table 6. Influence of some stimulating substances treatments on some macro elements contents (N, P and K) in the leaves of Washington navel orange trees during both 2013 and 2014 seasons.

\begin{tabular}{|c|c|c|c|c|c|c|}
\hline \multirow{3}{*}{ Treatments } & \multicolumn{6}{|c|}{ Leaf macro-elements contents } \\
\hline & \multicolumn{2}{|c|}{$\mathbf{N \%}$} & \multicolumn{2}{|c|}{$\mathbf{P \%}$} & \multicolumn{2}{|c|}{ K\% } \\
\hline & 2013 & 2014 & 2013 & 2014 & 2013 & 2014 \\
\hline Control (tap water) & $1.80 \mathrm{H}$ & $1.92 \mathrm{~F}$ & $0.27 \mathrm{G}$ & $0.30 \mathrm{G}$ & $1.26 \mathrm{H}$ & $1.32 \mathrm{G}$ \\
\hline $\mathrm{GA}_{3}$ at 75 ppm. & $2.47 \mathrm{EF}$ & $2.55 \mathrm{D}$ & $0.46 \mathrm{E}$ & $0.51 \mathrm{D}$ & $1.59 \mathrm{~F}$ & $1.44 \mathrm{~F}$ \\
\hline $\mathrm{GA}_{3}$ at $150 \mathrm{ppm}$. & $2.56 \mathrm{DE}$ & $2.59 \mathrm{D}$ & $0.50 \mathrm{CD}$ & $0.53 \mathrm{C}$ & $1.65 \mathrm{~F}$ & $1.51 \mathrm{EF}$ \\
\hline NAA at 25 ppm. & $2.13 \mathrm{G}$ & $2.27 \mathrm{E}$ & $0.38 \mathrm{~F}$ & $0.36 \mathrm{~F}$ & $1.49 \mathrm{G}$ & $1.31 \mathrm{G}$ \\
\hline NAA at 50 ppm. & $2.21 \mathrm{FG}$ & $2.54 \mathrm{D}$ & $0.41 \mathrm{EF}$ & $0.46 \mathrm{E}$ & $1.60 \mathrm{~F}$ & $1.51 \mathrm{EF}$ \\
\hline Sea-Weeds at $150 \mathrm{~mL}^{3} / \mathrm{L}$ & $2.85 \mathrm{CD}$ & $2.96 \mathrm{C}$ & $0.53 \mathrm{C}$ & $0.58 \mathrm{BC}$ & $1.73 \mathrm{E}$ & $1.59 \mathrm{E}$ \\
\hline Sea-Weeds at $200 \mathrm{~mL}^{3} / \mathrm{L}$ & $2.96 \mathrm{BC}$ & $3.18 \mathrm{~B}$ & $0.59 \mathrm{~B}$ & $0.63 \mathrm{AB}$ & $1.81 \mathrm{D}$ & $1.76 \mathrm{D}$ \\
\hline Yeast extract at $100 \mathrm{~mL}^{3} / \mathrm{L}$ & $3.19 \mathrm{AB}$ & $3.35 \mathrm{~A}$ & $0.62 \mathrm{AB}$ & $0.65 \mathrm{~A}$ & $1.88 \mathrm{C}$ & $1.82 \mathrm{CD}$ \\
\hline Yeast extract at $150 \mathrm{~mL}^{3} / \mathrm{L}$ & $3.33 \mathrm{~A}$ & $3.49 \mathrm{~A}$ & $0.66 \mathrm{~A}$ & $0.69 \mathrm{~A}$ & $1.98 \mathrm{~B}$ & $1.88 \mathrm{C}$ \\
\hline Proplis at $1.4 \mathrm{gm} / \mathrm{L}$ & $2.87 \mathrm{CD}$ & $2.55 \mathrm{D}$ & $0.61 \mathrm{AB}$ & $0.64 \mathrm{AB}$ & $2.01 \mathrm{AB}$ & $1.96 \mathrm{AB}$ \\
\hline Proplis at $2.8 \mathrm{gm} / \mathrm{L}$ & $2.66 \mathrm{CE}$ & $2.65 \mathrm{D}$ & $0.64 \mathrm{~A}$ & $0.68 \mathrm{~A}$ & $2.06 \mathrm{~A}$ & $2.04 \mathrm{~A}$ \\
\hline
\end{tabular}

Table 7. Influence of some stimulating substances treatment on some micro-nutrients contents (fe, $\mathrm{Zn}$ and $\mathrm{Mn}$ ) in the leaves of Washington navel orange trees during both 2013 and 2014 seasons.

\begin{tabular}{|c|c|c|c|c|c|c|}
\hline \multirow{3}{*}{ Treatments } & \multicolumn{6}{|c|}{ Leaf micro-nutrients contents } \\
\hline & \multicolumn{2}{|c|}{ Fe(ppm) } & \multicolumn{2}{|c|}{ Zn(ppm) } & \multicolumn{2}{|c|}{ Mn (ppm) } \\
\hline & 2013 & 2014 & 2013 & 2014 & 2013 & 2014 \\
\hline Control (tap water) & $23.79 \mathrm{~K}$ & $30.00 \mathrm{H}$ & $59.35 \mathrm{I}$ & $59.67 \mathrm{H}$ & $0.36 \mathrm{I}$ & $0.31 \mathrm{~J}$ \\
\hline $\mathrm{GA}_{3}$ at $75 \mathrm{ppm}$ & $38.49 \mathrm{I}$ & $41.00 \mathrm{G}$ & $68.67 \mathrm{H}$ & $68.33 \mathrm{G}$ & $0.63 \mathrm{EF}$ & $0.58 \mathrm{~F}$ \\
\hline $\mathrm{GA}_{3}$ at $150 \mathrm{ppm}$. & $42.90 \mathrm{G}$ & $46.00 \mathrm{E}$ & $73.33 \mathrm{G}$ & $74.00 \mathrm{~F}$ & $0.68 \mathrm{DE}$ & $0.62 \mathrm{E}$ \\
\hline NAA at $25 \mathrm{ppm}$. & $49.28 \mathrm{~J}$ & $52.00 \mathrm{G}$ & $66.33 \mathrm{~F}$ & $67.67 \mathrm{E}$ & $0.56 \mathrm{GH}$ & $0.51 \mathrm{I}$ \\
\hline NAA at $50 \mathrm{ppm}$. & $52.33 \mathrm{H}$ & $56.00 \mathrm{~F}$ & $70.67 \mathrm{E}$ & $71.67 \mathrm{D}$ & $0.61 \mathrm{FG}$ & $0.56 \mathrm{FG}$ \\
\hline Sea-Weeds at $150 \mathrm{~mL}^{3} / \mathrm{L}$ & $57.33 \mathrm{~F}$ & $60.00 \mathrm{D}$ & $75.33 \mathrm{D}$ & $78.00 \mathrm{C}$ & $0.73 \mathrm{CD}$ & $0.72 \mathrm{CD}$ \\
\hline Sea-Weeds at $200 \mathrm{~mL}^{3} / \mathrm{L}$ & $60.33 \mathrm{E}$ & $66.33 \mathrm{C}$ & $80.00 \mathrm{C}$ & $83.00 \mathrm{~B}$ & $0.79 \mathrm{C}$ & $0.73 \mathrm{C}$ \\
\hline Yeast extract at $100 \mathrm{~mL}^{3} / \mathrm{L}$ & $63.00 \mathrm{C}$ & $69.00 \mathrm{~B}$ & $86.00 \mathrm{~A}$ & $86.33 \mathrm{~A}$ & $0.84 \mathrm{~B}$ & $0.78 \mathrm{~B}$ \\
\hline Yeast extract at $150 \mathrm{~mL}^{3} / \mathrm{L}$ & $65.33 \mathrm{~A}$ & $70.33 \mathrm{~A}$ & $91.00 \mathrm{~A}$ & $90.00 \mathrm{~A}$ & $0.94 \mathrm{~A}$ & $0.86 \mathrm{~A}$ \\
\hline Proplis at $1.4 \mathrm{gm} / \mathrm{L}$ & $59.67 \mathrm{D}$ & $66.33 \mathrm{C}$ & $83.00 \mathrm{C}$ & $82.33 \mathrm{~B}$ & $0.51 \mathrm{H}$ & $0.56 \mathrm{H}$ \\
\hline Proplis at $2.8 \mathrm{gm} / \mathrm{L}$ & $64.33 \mathrm{~B}$ & $69.33 \mathrm{~A}$ & 89.00AB & 87.67AB & $0.57 \mathrm{H}$ & $0.56 \mathrm{FG}$ \\
\hline
\end{tabular}

The obtained data considering the response of leaf $\mathrm{Fe}, \mathrm{Zn}$ and $\mathrm{Mn}$ contents of Washington navel orange trees to different stimulating substances treatments in this study are coincident with that mentioned byAhmed et. al., (2013); Gambetta et al., (2014); Rizwen et al., (2014); Mahmoud et.al., (2015) and Ayed (2016).

\section{REFERENCES}

Abd El-Migeed, A.A.A.E; Eman, M.M.M. A.;Omayma, M.M.I. (2007). $\mathrm{GA}_{3}$ and Zinc spray for improving yield and fruit quality of Washington navel orange trees grown under sandy soil conditions. Research Journal of Agriculture and Biological Sciences; 3(5) : 498-503.

Abd El-Motty, E.Z.; Mohamed, F.M. Shahin; Mohamed, H. El- Shiekh and Mahmoud, M.M.

AbdEl-Migeed (2010). Effect of algae extract and yeast application on growth, nutritional status, yield and fruit quality of keitte mango trees agric. Biol. J. N. Am., 2010, 1(3) : 421429

Abd El-Motty, Elham, Z. and Salwa, Orabi, A. (2013). The Beneficial effects of using zinc, yeast and selenium on yield, fruit quality and antioxidant defense systems in navel orange trees grown under newly reclaimed sandy soil, Journal of Applied Sciences Research, 9(10) : 6487-6497.
Ahmed Y.M. and Osama A.M.E. (2013). Effect of Seaweed Extract on Fruiting of Hindy Bisinnara Mango Trees. Journal of American Science; 9(6) : 537-544.

Association of Official Analytical Chemists. A.O.A.C. (2000). Official Method of Analysis, 17th Ed., Inc., USA.

Atawia, A.A. R. and El-Desouky, S.A. (1998). Trials for Improving fruit set, yield and fruit quality of Washington Navel Orange by application of some growth regulators and yeast extract as natural source of phytohormones. Annals of Agricultural Science, Moshtohor; 35 (3) : 1613-1632.

Ayed, M.E.A., (2016) . Physiological Studies on Washington navel orange trees grown in new reclaimed soils. M./Sc. Thesis, Faculty of Agric, Moshtohor, Benha University.

Castrol, P.R. C.; Virgens Filho, A. C. and Medina, C.L. (1998). Effect of Fungicides, gibberellic acid and plant stimulant on sprouting and fruit se of pera (citrus sinensis L. Osbeck) orange tree. Acta Horticulturae; 463 : 311-315.

Chapman, H. D. and Pratt, P.F. (1961). Methods of Analysis for Soil, Plant and Waters. Univ. of Calif. Division of Agric. Sc. $6^{\text {th }}$ Ed. P. 56-64.

Chen, P. M. and W. M. Mellenthin (1981). Changes in ripening behaviour of $d$ Anjou pears (pyrus communisl). After cold storage scientia-Horticulture, 12 (2) 137-146 (c. F Hor. Abst : 146). 
Duncan, D.B. (1955). Multiple range and multiple f. Tests Biometerics, $11: 1-42$

El-Shazly, S.M. and Mustafa, N. S. (2013). Enhancement yield, fruit quality and nutritional status of Washington Navel Orange Trees by application of biostimulants. Journal of Applied Sciences Research; 9(8) : 5030-5034.

Faissal, F.A.; Akl, M.M.A. and Ahmed, A.F.O. (2013). Partial replacement of inorganic nitrogen fertilizer by spraying some vitamins, yeast and sea-weeds extract in Ewise mango orchard under upper Egypt condition. Hort. Dept., Fac. Of Agric. Minia Univ. Egypt.

Fathy, E-S. L. and Farid, S. (1996). The Possibility of using Vitamin B and Yeast to delay senescence and improve growth and yield of common beans (phaseolus vulgaris L.) J. Agric. Sci. Mansoura Univ.; 21 (4) : 1415-1423.

Fornes, F.; Sanchez-Perales, M. and Guardiola, J. L. (2002) . Effect of a sea-weeds extract on the productivity of "de Nules" clementine mandarin and Navelina Orange. Botanica Marina; 45(5) : 486-489.

Gambetta, G.; Mesejo, C.; Martinez-Fuentes, A.; Reig, C.; Gravina, A. and Agusti, M. (2014).

Gibberellic acid and Norflurazon affecting the timecourse of flavedo pigment and abscisic acid content in "Valencia" sweet orange. Scientia Horticul turae, 80:94-101.

Ghosh, S. N.; Bera, B. and Roy, S. (2013). Influence of Plant Growth Regulators on Fruit Production of sweet orange, Journal of Crop and Weed; 8(2) : 83-85.

Jackson, M. L. and A. Ulrich (1959). Analytical methods for use inplant analysis. Coll. Of Agric. Exp. State Bull. 766 : 35pp.

Kabeel, H. (1999). Effect of Some growth regulators on fruit set, yield and fruit quality of "costata" persimmon trees minufiya Jour. Agric. Res., 24 (5) : 1727-1739.

Khafagy, S. A. A.; Zaied, N. S.; Nageib, M. M.; Saleh, M. A. and Fouad, A. A. (2010).

The beneficial effects of yeast and zinc sulphate on yield and fruit quality of Navel orange trees. World Journal of Agricultural Sciences, 6(6):635-638.
Khan, A. S.; Shaheen, T.; Malik, A. U.; Rajwana, I. A.; Ahmad, S. and Ahmad, I. (2014). Exogenous applications of plant growth regulators influence the reproductive growth of (Citrus sinensis l. Osbeck) cv. Blood Red. Pakistan Journal of Botany; 46 (1) : 233238.

Koo, R. C. J. and Mayo, S. (1995). Effects of sea-weeds sprays on citrus fruit production. Proceedings of the Florida State Horticultural Society; 107:82-85.

Mahmoud, Thanaa, Sh.;Nabila, Kassim, E. and Abou Rayya, M.S. (2015). Effect of Foliar Application with Dry Yeast Extract and Benzyladenine on Growth and Yield of Manzanillo Olive Trees. Research Journal of Pharmaceutical, Biological and Chemical Sciences, 6 (2) : 1573-1583.

Murphy, J. and J.P. Riely (1962). A modified single method for the determination of phosphorus in natural water.Anal. Chemi- Acta, $27: 31-36$.

Munoz-Fambuena, N.; Mesejo, C.; Gonzalez-Mas, M. C.:Iglesias, D.J.; Primo-Millo, E. and Agusti, M. (2012). Gibberellic acid reduces flowering intensity in sweet orange (Citrus sinensis L. Osbeck) by Repressing CIFT gene expression, Journal of Plant Growth Regulation; 31(4) : 529-536.

Pregl, E. (1945). Quantitative Organic Micro Analysis. $4^{\text {th }}$ Ed. Chundril London.

Rizwan Ullah; Sajid, M.; Ahmed, H.; Luqman, M.; Razaq, M.; Nabi, G.; Fahad, S. and Rab,

A. (2014). Association of Gibberellic acid $\left(\mathrm{GA}_{3}\right)$ with fruit set and fruit drop of sweet orange. Journal of Biology, Agriculture and healthcare, 4(2):54-59.

Snedecor, G. W. and Cochran, G. W. (1990). Statistical Methods. $8^{\text {th }}$ Ed The Iowa State Univ.,Press Amer., Iowa. U.S.A., pp. PP. 503-507.

Ullah, R.; Sajid, M.; Nabi, G.; Ahmed, H.; Rab, A.; Khan, F.A.; Shahab, M.; Subthain, H.; Fahad, S. and Khan, A. (2014). Gibberellic acid $\left(\mathrm{GA}_{3}\right)$, an Influential growth regulator for physiological disorder control and protracting the harvesting season of sweet orange. American Journal of Experimental Agriculture, 4(11) : 1355-1366.

GuiYuan ,W.; Xu-Feng; Xia-RenXue; XiangGuo, Z. and QTangSheng W. (2013). Dynamic changes in sugar concentrations in the fruit peel of "cara" navel orange (Citrus sinensis L. / Osbeck) after exogenous application of ABA and $\mathrm{GA}_{3}$. Philippin Agricultural Scientist. 96(1):26-31.

Westwood, M.N. (1978). Temperate Zone Pomology W.H. Freeman and Company. San Francisco.

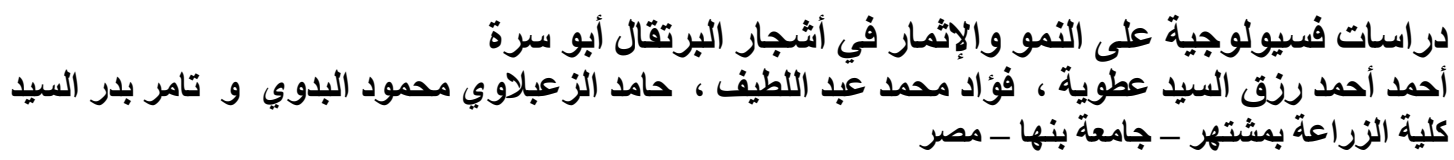

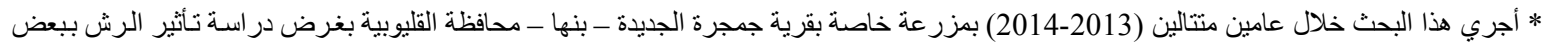

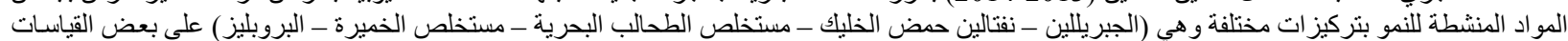

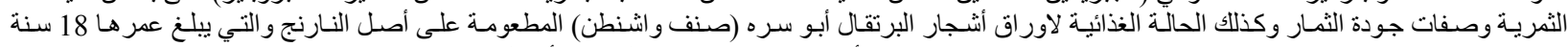

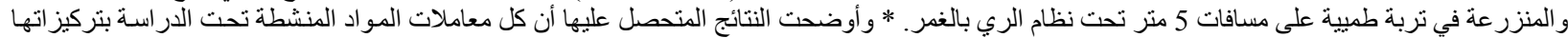

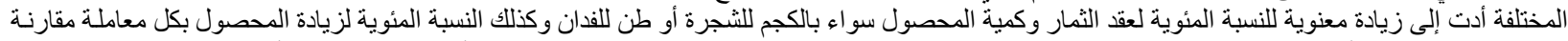

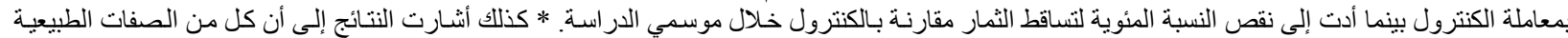

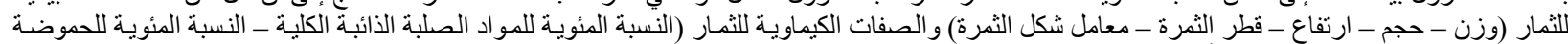

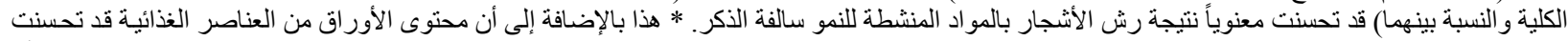

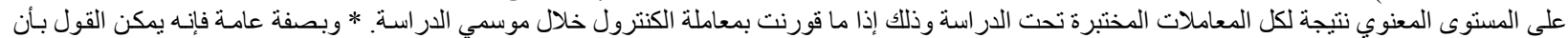

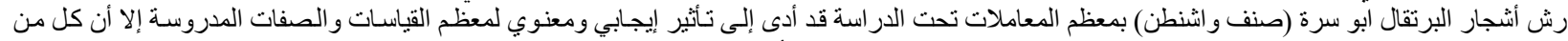

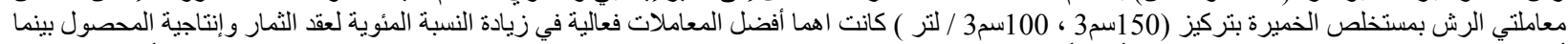

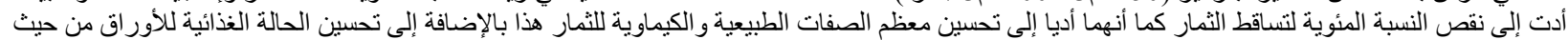
محتو اها من العناصر الغذائية. 